Indian branch of the Ross Institute, started in 1930, is mainly concerned with the control of malaria in the tea and coffee estates, rubber plantations, mines, sugar factories, cotton and jute mills and other industries in various parts of India. The chief function of the Central Co-operative Society of Bengal is propaganda, in which it has been very successful as it has 2,362 rural societies under its control. These various organizations co-operate freely both in general conferences and in joint inquiries and investigations.

\section{Empty Space}

Dr. Robert G. AItken brings together some interesting information on this topic in Leaflet No. 148 issued by the Astronomical Society of the Pacific. The diameter of the universe made accessible by the 100-inch telescope is about 600 million light-years, and the 200-inch telescope will double the diameter of this sphere. In this smaller sphere there are 100 million stellar systems with an average content of $10^{10}$ stars, the diameters of which average about twice that of our sun. The stars fill about $10^{-26}$ part of space and it is believed that the space between the separate stellar systems-extragalactic spaceis absolutely empty. In interstellar space, however, in which the stars are distributed at average distances of five or six light-years, electrons, protons, atoms, gas molecules, minute dust particles and also larger pieces of matter, ranging up to the size of meteorites, are known to exist.

There is so much space that the mass of this interstellar matter may be two or three times the combined mass of all the stars, and, with the exception of the larger pieces of matter, the interstellar particles produce a number of problems for the astronomer because of their effect in absorbing and scattering light. The light from the more distant stars passes through space laden with gas molecules, and the intensity of the stellar lines will increase with increasing distance-a fact which has been utilized in recent times to estimate the distances of these stars. Previous conclusions regarding the distances of the fainter stars based on the inverse square relationship must now be modified, and these distances may not be so great as astronomers believed a few years ago. Another important point is the greater absorbing and scattering effect upon the shorter violet rays, and in consequence myriads of stars cannot be photographed by the use of ordinary photographic plates. Many thousands of stars, the existence of which had been previously unsuspected, have recently been photographed with new red-sensitive platesconvincing evidence of the presence of interstellar matter. An enormous field for research in this direction lies before the astronomer.

\section{Two Notable French Men of Science}

ON August 21 and 22 respectively occurred the centenary of the death of one distinguished Frenchman and the bicentenary of the birth of another. The first of these men is the eminent geologist and civil engineer Jean François d'Aubuisson de Voisins, who was born in the South of France on April 16,
1769 , and died at the age of seventy-two on August 21, 1841. For four years D'Aubuisson was a student under Werner at the Mining School at Freiburg, and it was while in Germany that he studied the basalts of Saxony, an essay on which he published in Paris in 1803. This essay, in which the Wernerian doctrines were adopted, was reported on by Haüy and Ramond, who advised the author to inspect the basalts of Auvergne. This D'Aubuisson immediately did, with the result that in a paper "Sur les volcans et les basaltes de l'Auvergne", read to the French Institute in 1804, he abandoned many of the views he had hitherto held. "The facts which I saw", he wrote, "spoke too plainly to be mistaken; the truth revealed itself too clearly before my eyes, so that I must either have absolutely refused the testimony of my senses in not seeing the truth, or that of my conscience in not straightway making it known." D'Aubuisson's most important work was his "Traité de Géognosie", published in 1819, but he was also known for his investigation in hydraulies (1826-30) and his "Traité d'Hydraulique, à l'usage des Ingénieurs", an enlarged edition of which, published in 1840, was translated into English by Bennett and published at Boston, Massachusetts, in 1852 .

The other Frenchman to whom we refer is the naval officer and navigator Jean-François Galaup de La Pérouse, who met a tragic fate following in the footsteps of Cook. La Pérouse was born at Albi, in the department of Tarn, August 22, 1741, and at an early age entered the French Navy. When serving in the Formidable under Conflans against Hawke, he was wounded and taken prisoner. During the peaceful years of 1764-78 he did all in his power to fit himself for his profession, and in the Astrea in 1782 showed much skill and resource in penetrating into the Hudson Bay and capturing several British posts. The reputation he gained led to his appointment to command the expedition comprising the ships Boussole and Astrolabe, which left Brest on August 1, 1785, to visit the Pacific. Crossing to South America, the ships rounded Cape Horn and from thence proceeded to California, China, the Philippines and Kamschatka. Sailing south again, La Pérouse reached Australia in the beginning of 1788 and from Boteny Bay sent a letter to the French Minister of Marine giving particulars of the voyages he intended to make. From that time onwards for many years nothing was known of the fate of the ships. In 1791 Admiral d'Entrecasteaux in the Research and Espérance searched in vain for them, but some meagre information was secured by the ship Hunter, which, sailing from Bengal in 1813, visited Australasia. On board the Hunter was Peter Dillon (1785?-1847) who as captain of the Saint Patrick in 1826 discovered that the Boussole and Astrolabe had been wrecked off Vanikoro, north of the New Hebrides. Dillon made a second voyage in the Research and brought back to France many relics of the unfortunate expedition. For his services he was made a chevalier of the Legion of Honour. There is a bronze statue of La Pérouse at Albi, and his name has been given to the strait between Sakhalin and Yezo. 